\title{
Innovation Onset: A Moderated Mediation Model of High-Involvement Work Practices and Employees' Innovative Work Behavior
}

\author{
Mingxing Li (1) ${ }^{\prime}$, Hira Salah ud din Khan $\mathbb{D}^{\prime}$, Muhammad Salman Chughtai $\mathbb{D}^{2}$, Thanh Tiep Le $\mathbb{D}^{3}$ \\ 'School of Management, Jiangsu University, Zhenjiang, The People's Republic of China; ${ }^{2}$ Faculty of Management Sciences, International Islamic \\ University, Islamabad, Pakistan; ${ }^{3} \mathrm{Ho}$ Chi Minh City University of Economics and Finance, Ho Chi Minh City, Vietnam
}

Correspondence: Hira Salah ud din Khan, School of Management, Jiangsu University, 30I Xuefu Road, Zhenjiang, 2I20I3, The People's Republic of China, Email hirakhan@ujs.edu.cn; Muhammad Salman Chughtai, Faculty of Management Sciences, International Islamic University, Islamabad, Pakistan, Email salman.phdmgt80@iiu.edu.pk

Purpose: Based on the componential theory of creativity, this study examined the link between high-involvement work practices and employees' innovative behavior by further investigating the moderating and mediating role of leadership humility and employees' personal initiative.

Methodology: To test the hypothesized model, the data were gathered from 255-line staff and 119 supervisors working in the textile industry in Pakistan via the time lag technique. The proposed hypotheses were analyzed through partial least squares structural equation modeling using Smart-PLS software.

Findings: The results indicated that high-involvement work practices were significantly related to employees' innovative work behaviors. Additionally, the moderation findings revealed that a higher level of leadership humility strengthens the relationship between high-involvement work practices and employees' personal initiative. Furthermore, employees' personal initiative mediates the relationship between high-involvement work practices and their innovative work behavior. The findings of the moderated mediation model indicated that a higher level of leadership humility leads to higher innovative behavior of employees in the presence of highinvolvement work practices via employees' personal initiative.

Practical Implications: This study's findings are helpful for the management of organizations to understand the factors that enhance innovative work behaviors in high-involvement work practices. Moreover, managers should establish humble behaviors in their leadership style to influence employees' personal initiative, which indirectly influences their innovative work behavior.

Originality/Value: The present study highlights the importance of leadership humility and employees' personal initiative in the relationship between high-involvement work practices and innovative work behaviors of employees in the textile industry of Pakistan. Keywords: high-involvement work practices, employees' innovative work behaviors, employees' personal initiative, leadership humility

\section{Introduction}

The work environment dynamics in terms of technology, innovation, and cutthroat competition required for organizational success changed at the beginning of the 21 st century. ${ }^{1,2}$ Scholars have argued that an innovative atmosphere contributes to the country's economy and the nation's progress. ${ }^{3}$ Given this, innovative behaviors of the workforce positively impact uncertain market conditions and demand. ${ }^{4,5}$ Scholars have elaborated that it is not easy for the human brain to generate novel ideas that are practical, accurate, and realizable. ${ }^{6}$ Thus, organizations encourage and promote innovative behaviors among their workforce with positive leadership. ${ }^{5,7}$ Further, innovative work enables survival in an uncertain, challenging environment and enhances organizational efficiency., ${ }^{8,9}$ Innovative work behavior in the manufacturing sector is concerned with the generation of new and novel ideas or methods, which is not only beneficial for the manufacturing process but also for the quality of the products. ${ }^{10}$ In line with this, organizations hire individuals who 
possess innovative qualities and characteristics. ${ }^{11}$ Researchers have suggested that organizational performance depends on employees' personal resources, ${ }^{12,13}$ which stimulates innovative behavior than financial, technical, and mechanical resources. ${ }^{14-16}$ There is a substantial body of literature on innovation or innovative work behavior in different organizational contexts, such as education, engineering, business, technology, and management. ${ }^{5,17,18}$ However, especially in the manufacturing sector, there is a need for discussion on the introduction of new tactics of cost reduction and enhancement of quality products with the support of leadership and motivation. ${ }^{19}$

Generally, the human resource system of an organization affects organizational performance. ${ }^{20}$ Researchers have argued for a thorough review of specific procedures that are important for understanding the impact of human resource Management practices on workers. ${ }^{21}$ In contrast to high-performance work practices, high-involvement work practices (HIWPs) are usually more associated with employees' work-related behaviors. ${ }^{22,23}$ Scholars have characterized HIWPs as a set of organizational policies and practices utilized by organizations to enhance the qualities and skills of their workforce through sharing of power, knowledge, information, and rewards ${ }^{24,25}$ Researchers have found that HIWPs are linked to positive outcomes, such as increased performance. ${ }^{26}$ In addition, HIWPs enable empowerment, networking, appreciation, team building through rewards, knowledge sharing, and training that encourage employees to participate in decision-making, leading to innovation. ${ }^{27,28}$ Implementing HIWPs in the organization requires highly involved employees who progress in the workplace. ${ }^{22}$ Additionally, HIWPs provide a platform that induces a supportive work atmosphere where management/leadership encourages employees, ultimately resulting in high levels of employees' innovative work behaviors (EIWBs). ${ }^{29}$ Researchers defined EIWBs as an array of positive behaviors of employees in the workplace for initialization, adoption, and implementation of new and novel ideas, through which renewal of products and services becomes possible by altering the process and production methods for organizational success. ${ }^{17,30}$ In line with this, this study argues that HIWPs represent a valuable resource that augments EIWBs.

Scholars have identified that HIWPs offer the flexibility of the organizational structure through job characteristics, autonomy, self-managed work groups, open two-way interaction, decision-making involvement, wide-ranging skill development, lesser disparities, and appraisal and reward strategies. ${ }^{31-33}$ HIWPs also encourage workforce involvement in organizational activities that increase employee autonomy ${ }^{34}$ and augment workforce commitment by appealing to inner drive. ${ }^{35}$ As a result, HIWPs improve staff skills and behaviors that support strategic planning and implementation and thereby execute a strategic human resource function to achieve organizational efficiency. ${ }^{28,36}$ Employees' personal initiative (EPI) plays a significant role in accomplishing these organizational goals by aligning their actions with their proactive and self-initiative abilities. ${ }^{37,38}$ Scholars defined personal initiative as:

work behavior characterized by its self-starting nature, its proactive approach, and by being persistent in overcoming difficulties that arise in the pursuit of a goal. ${ }^{39}$

Further, the success of any organizational innovation strategy depends on the workforce and the need for effective leadership styles to successfully accomplish organizational goals for the sustainability of competitive advantage in the market. ${ }^{40}$ Moreover, the importance of leadership is recognized as an essential factor for improving innovative ideas, especially in the manufacturing sector, as the workforce of this sector is more susceptible to engender and implement novel thoughts. ${ }^{19}$ Recently, the concept of leadership humility (LH) has received attention as this leadership style has the quality of listening, observing employees, and encourages a learning environment. ${ }^{41}$ Leadership humility is defined as bottom-up leadership to enhance the capacities of their subordinates/followers by utilizing the interpersonal skills of teachability, encouragement, and openness to experience new things. ${ }^{41-43}$ Leaders who possess the attributes of humility do not hold large egos and are not anxious about status. Moreover, these leaders tend to share credit and recognize the accomplishments of others rather than seeking attention or acknowledgment for themselves. ${ }^{44}$ Scholars have stated that LH entails a positive approach toward their subordinates in that humans are not perfect ${ }^{41}$ and there are chances of mistakes. This humble behavior of leaders and positive signals not only provide motivation but also provide safety for taking a risk during the process of decision-making, which not only produces positive behaviors in the form of innovation and creativity ${ }^{41-43}$ but also forces them to take the initiative for these behaviors. Scholars have suggested that, in the presence of LH, subordinates are willing to take critical challenges and solve critical problems easily. ${ }^{41-43}$ Higher levels of LH also increase the level of EPI. Previous studies demonstrated that LH intensifies subordinates/followers' 
motivation and involvement to take an active part in the work environment, which ultimately heightens innovative ideas. ${ }^{42,43}$ Thus, this study asserts that LH serves as a moderating variable in the relationship between HIWPs and EPI.

From the perspective of innovativeness, the role of leaders is predominantly captured to highlight that leadership serves as a vital source to aid in developing, shaping and retaining desired organizational structure, which ultimately influences EIWB. ${ }^{45}$ Nonetheless, gaps related to HIWPs and innovation have been identified. Scholars have conceded that specific personal or organizational factors enhance or undermine employees' innovative ideas or creativity. ${ }^{20}$ The personal initiative enables employees to achieve organizational goals and objectives. ${ }^{46}$ Recently, EPI has been revealed to be highly essential for organizations. ${ }^{47}$ Studies have indicated that organizations demand employees who "think outside the box" to accomplish their tasks by demonstrating personal initiative to find solutions. ${ }^{48,49}$ Personal initiative is more than creativity since it is important to step forward and successfully implement innovative ideas. ${ }^{50}$ Scholars have elaborated that organizations must recruit employees who dare to take the initiative and demonstrate analytical thinking with an innovative approach to meet the challenges of unpredictable changes and upgrade their knowledge and skills. ${ }^{39}$ Thus, EPI serves as a mediating mechanism in HIWPs and EIWBs.

The componential theory of creativity (CTC $)^{16,51}$ emphasizes the different factors that influence creativity, such as organizational and social environment, motivation, and cognitive ability of individuals. ${ }^{52,53}$ Moreover, CTC explains that social and psychological aspects also influence the cognitive level that enforces the generation, execution, and implementation of new and novel ideas. ${ }^{54}$ In addition, leadership support boosts the motivation level of individuals in the form of their personal initiative level. ${ }^{54}$ A positive work environment in the form of HIWPs also promotes individuals' selfmotivation, which also fosters innovative work behaviors. ${ }^{53,55}$ Building on the CTC, ${ }^{16,51}$ this study develops this perspective by exploring the black box of $\mathrm{LH}^{54}$ which may enhance the level of personal initiative ${ }^{52}$ that further fosters innovative work behaviors in the workplace using HIWPs. ${ }^{53}$ Even though HIWPs are an important concept in contemporary literature on workplaces, most studies have been limited to Western manufacturing contexts $\left(\mathrm{see}^{56-58}\right.$ ). However, the picture for Asian developing economies is unclear. Only a few empirical studies in Asian countries have examined HIWPs with respect to EIWBs (eg, ${ }^{59-61}$ ). Consequently, there is a need to investigate HIWPs and EIWBs in numerous manufacturing sectors worldwide.

In light of the above discussion, this study investigates the following objectives by employing the CTC concept: 1) The impact of HIWPs on EIWBs in Pakistan's manufacturing (textile) industry. 2) The moderating role of LH in the relationship between HIWPs and EPI. 3) The mediating impact of EPI on the link between HIWPs and EIWBs. 4) The moderated mediation effects of LH and EPI in the direct relationship between HIWPs and EIWBs in Pakistan's textile industry, as illustrated in Figure 1. Consequently, the empirical results will serve as a guide for future research in this area. The following section briefly reviews the relevant literature to provide context for the study. This is accompanied by the methodology adopted. Subsequently, the major findings are reported and discussed. The article concludes with a discussion of the implications of the results and areas of research for further investigation and insight.

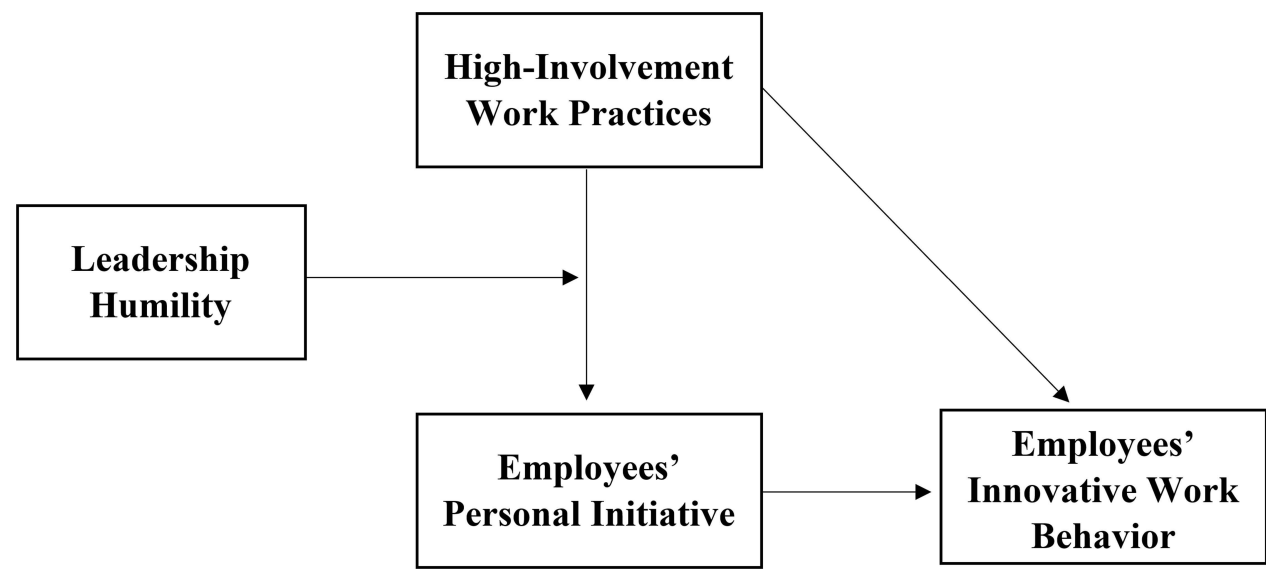

Figure I Conceptual framework demonstrates the relationship among the variables of the study. 


\section{Theoretical Foundation}

This study's model is based on the CTC, ${ }^{16,51}$ which explains the creative processes and other factors that affect the process. CTC was extended ${ }^{62}$ with individual/organizational creativity and innovation influenced by cognitive ability, motivation, and social and organizational environment. CTC explains four significant factors (ie, domain-relevant skills, creativity-related processes, task motivation, and social environment) that predict creativity/innovation and new ideas. ${ }^{16,51,62}$ In line with this, human resource strategies are well adopted in HIWPs to build and strengthen a personality and self-managing workforce. ${ }^{22}$ According to the CTC, self-motivation, cognitive abilities, expertise, technical skills, factual knowledge, brilliance, and social skills are the top personal qualities that act as a mechanism for individuals to solve workplace challenges and promote creativity and innovation. ${ }^{16}$ Conversely, lack of motivation, skills, unwillingness, and social skills inhibit creativity and innovation. ${ }^{16}$ Regarding this, EPI represents self-starting, future-oriented to realize organizational goals; ${ }^{63}$ such proactive behaviors stimulate innovation. Further, in harmony with CTC, workforce employee social (communication, empowerment, and reward) and psychological (skill development, recognition) factors are necessary for an individual to generate and share new ideas, policies, and demonstrate innovative behavior in the workplace. ${ }^{62}$ By emphasizing inner inspiration and innovation, we believe that the CTC offers a rich conceptual framework to examine the key moderating mechanism of LH, which serves as a vehicle in the link between HIWPs and EPI. Leadership Humility motivates subordinates through guidance and a positive environment by giving value to the ideas, involvement, and engagement of employees during the process of strategy and decision-making. ${ }^{42,43}$ Furthermore, LH not only encourages the new ideas of subordinates but also gives value to the feedback they receive; on the other hand, these leaders are enthusiastic about learning from others, but they also possess the ability to accept criticism and create a comprehensive organizational environment. ${ }^{42,43}$ The behaviors of these leaders make it easy for their subordinates to show positive behaviors and increase the level of safety, which further results in an increase in taking risks ${ }^{41}$ and initiative. Based on CTC, this study employed HIWPs (ie, empowerment, communication, performance evaluation, recognition and reward, and skill development) as an antecedent (external, social, and environmental factors) of EIWBs. Furthermore, EPI was investigated as an intervening variable between HIWPs and EIWBs, and LH was used as a moderating variable between HIWPs and EPI.

\section{High-Involvement Work Practices and Employees' Innovative Work Behavior}

High Involvement Work Practices are the key practices concerned with employees' success to improve their competencies and motivation in the workplace. ${ }^{64}$ Additionally, HIWPs are the practices adopted by organizations to improve workforce skills through power, information, rewards, and knowledge. ${ }^{24,25}$ These practices are not only helpful for individual performance but also for organizational performance by offering opportunities for growth, such as training and development and performance appraisal. ${ }^{56}$ Organizations implement HIWPs for the investment in their human talent by boosting the confidence and morale of employees to attain organizational objectives. ${ }^{65}$ Lawler $^{33}$ suggested five supportive human resource practices (skill development, performance evaluation, communication, empowerment, recognition, and reward) as HIWPs ${ }^{66-69}$ that influence the individuals' performance and attitudes. ${ }^{70}$ Scholars have expressed that HIWPs enable employees to achieve organizational goals and vision. ${ }^{71}$ Corroborating this, the business environment is rapidly changing due to high competition, and there is a need for consistent innovation in organizations ${ }^{72}$. Innovation is an essential element for enhancing organizational performance. ${ }^{73}$ Implementation of HIWPs enables the individuals to adapt the latest technology, ${ }^{57}$ which further results in innovative behaviors.

The concept of EIWBs is multidimensional and includes the productive working behaviors of individuals for the initialization and implementation of novel and valuable ideas through exploration, generation, and application opportunity. ${ }^{17,74}$ Different scholars have argued that EIWBs are concerned with the behaviors of employees related to the development, adoption, and implementation of new and unique ideas within the scope of the organization. ${ }^{30}$ Studies have specified that innovative ideas are important for renewing products and services with new techniques and methods for organizational success. ${ }^{6,75}$ EIWBs are beneficial for organizations as these behaviors provide new methods and procedures for developing new products and services ${ }^{19}$ and benefit individuals. These benefits of innovative behavior play an influential role in the organization's long-term survival and effectiveness. ${ }^{73}$ It is noted that employees' quality 
performance increases with the adoption and implementation of HIWPs. ${ }^{76}$ Moreover, industrial organizations usually implement HIWPs to become more meaningful and achieve strategic goals through their workforce's innovative activities. ${ }^{36}$ Several outcomes of HIWPs have been discussed in previous literature, but there is little discussion on their impact on EIWBs. ${ }^{77,78}$ Some studies revealed that burnout is one of the negative consequences of HIWPs. ${ }^{79}$ This inconsistency is ongoing, and it necessitates a new line of research to better understand HIWPs and their consequences. ${ }^{80}$ On the other flip side, numerous studies indicated that adoption and implementation of HIWPs in the organization produces several positive outcomes, that is, higher organizational performance, ${ }^{81}$ reduction in turnover, ${ }^{70}$ increased work engagement, ${ }^{82}$ and learning goal-orientation, ${ }^{83}$ higher job satisfaction, ${ }^{84,85}$ higher-earning, ${ }^{86}$ higher creative performance, ${ }^{87} \mathrm{OCB},{ }^{88}$ an adaptation of technology,${ }^{57}$ human potential and motivation ${ }^{56}$ and higher wellbeing. $^{84}$

Further, to develop innovative behaviors, employees need a certain skills and attributes such as effective communication, sharing of knowledge and information. ${ }^{89}$ Accordingly, HIWPs comprises of those set of rules which enables the employees to be highly responsible, willing to accept innovative challenges enthusiastically that results into EIWBs. Also, recent studies asserted that HIWPs works as physical and psychological resources for the employees to meet the demands of the organizations, ${ }^{90}$ and these psychological resources also enable the individuals for the reduction of negative consequences, ie, burnout, ${ }^{80,91-93}$ CWBs. ${ }^{94}$ Notably, we focused on staff' HIWPs experiences in our study rather than managerial perceptions of HIWPs. According to Li et al, ${ }^{95} \mathrm{HRM}$ systems established at the institutional level must be understood by individual employees in an effort to have an effect on the organization. Based on CTC and the discussion above, we formulate the following hypothesis:

Hypothesis 1 There is a positive association between HIWPs and EIWBs.

\section{Leadership Humility as Moderator}

Management literature emphasizes the importance of leadership; it is a central component of success for every organization, as leaders direct the working responsibilities to their subordinates, evaluate their working performance, and control their subordinates' access to superfluous resources and information. ${ }^{96}$ Humility helps the leaders to enhance the trust, fellowship, and commitment level toward the organization. ${ }^{97}$ So, LH is a leadership style that works through learning and listening to others by utilizing the bottom-up approach. ${ }^{41,42}$ Leadership humility is an influential management tool that increases organizational performance and provides the environment of collaborative behaviors and information sharing, which are necessary for organizations, ${ }^{43,98}$ especially in the current complex era of working conditions and competition. It is evident that HIWPs boost individuals to work hard with more responsibility and diligently. ${ }^{25}$ Support of positive leadership in the form of LH also motivates and encourages individuals to produce positive outcomes. ${ }^{54}$

Contrarily, scholars found that LH has dual aspects positive and negative, for instance, LH leads to workplace deviance through their psychological entitlement; on the other hand, LH decreases subordinates' workplace deviance through Leader member exchange. ${ }^{99}$ Additionally, it has also been observed that employees feel an imbalance between work and family life because of higher demands and long working hours, due to HIPWS at the workplace. ${ }^{79}$ Furthermore, leaders who display teachability, that is, seeking for and accepting guidance and assistance, emphasize their reliance on others, thus decreasing perceptions of autonomy. ${ }^{100}$ Similarly, while acknowledging the achievements of others, humble leaders emphasize the accomplishments of others rather than their own; this de-emphasis of the leader's accomplishments can imply a lack of autonomy, which is another important factor of agency. ${ }^{101}$ While humility has a negative impact on societal characteristics, it has a positive effect on the EIWBs in the organization. For instance, empirical studies have demonstrated that LH promotes an encouraging environment that leads to several positive outcomes, ie, innovation, ${ }^{102}$ firm innovativeness, ${ }^{40}$ psychological empowerment, ${ }^{103}$ employees' proactive behavior, ${ }^{104}$ well-being and psychological safety, ${ }^{105}$ resilience, ${ }^{106}$ team job crafting, ${ }^{107}$ and reduces emotional exhaustion ${ }^{79,108}$ and $\mathrm{CWBs}^{109}$ of their subordinates/followers. Moreover, the implementation of HIWPs (ie, empowerment, skill development, communication, performance evaluation, reward, and recognition) by the organization demonstrates a positive gesture to their workforces in the form of appreciation and encouragement. ${ }^{110}$ Therefore, it is argued that HIWPs helps the 
organizational leadership in terms of motivation enabling the leaders to influence their subordinates for positive attitudes and behaviors, as LH promotes supportive behaviors and team work through cooperation and coordination at the workplace. ${ }^{111}$

Furthermore, employees with a strong sense of personal initiative are more motivated and persistent in their idea generation, engagement, and realization efforts. ${ }^{112}$ Therefore, this study contends that when leaders show humility through proactivity and a culture of collaboration, it enhances the level of personal initiative with the utilization of HIWPs toward innovation and high competency ${ }^{113}$ because when leaders become humble, this encourages employees' capabilities and strengths of their subordinates/followers. ${ }^{114}$ Thus, employees put their efforts, knowledge, and skills to accomplish the organizational goals. ${ }^{115}$ Given this, LH acts as a catalyst that enhances the EIWBs. Based on the above discussion, we formulate the following hypothesis:

Hypothesis 2 LH moderates the relationship between HIWPs and EPI in such a way that a higher level of LH will increase the level of EPI.

\section{Employees' Personal Initiative as a Mediator}

Employee Personal Initiative is concerned with the behavior of humans at the workplace, which is consistent with three components: proactivity, self-starting, and determination. ${ }^{37}$ In addition, EPI is a set of behaviors that enables individuals to accomplish long-term organizational goals by focusing on the direction and action of goal achievement by overcoming barriers through the utilization of proactivity and self-starting. ${ }^{38}$ Personal initiative is based on the underlying notion that individuals are affected by their surroundings and personal interests ${ }^{39}$ and concerned with future-oriented behaviors of employees that go beyond their job description. ${ }^{39,46}$ Employee Personal Initiative explained the employees' positive psychological states, which are related to the achievement of organizational objectives, without any external pressure, requirement, or instructions by the management. ${ }^{39,46,116}$ Individuals' proactive behavior is related to the long-term emphasis on attaining organizational objectives that enable individuals to overcome daily challenges. ${ }^{39,46}$ Subsequently, employees persistence demonstrates their proactive behavior and capacities for attaining goals. ${ }^{39,46}$

Proactive behaviors help individuals to strengthen their job strategies, processes, and the development of necessary personal requirements to achieve potential job expectations. ${ }^{49}$ The presence of HIWPs in organizations boosts the motivation of individuals, ${ }^{52,55}$ which enhances their proactivity, self-determination, and starting, thereby cognitively fostering them to produce innovative behaviors in the workplace. Innovation generally requires personal initiative as the process of innovational demands and self-starting behavior with a long-term focus and the ability to overcome the barriers to achieving innovative goals and objectives. ${ }^{117}$ Organizations that apply social and organizational settings (HIWPs) impact the cognitive abilities and self-motivation of individuals ${ }^{52}$ through which they take initiatives that enable them to produce new and novel ideas and make their job meaningful and exciting. ${ }^{118}$ Furthermore, it has been revealed that higher personal initiative with employees' positive acuities about the work environment leads to higher job satisfaction. ${ }^{119}$

The higher level of EPI provides individuals with the potential for organizational development and becomes loyal to their organizations, further increasing their job/career satisfaction. ${ }^{120,121}$ Numerous studies have shown that personal initiative produces several positive outcomes: self-efficacy, career success, idea quality, active coping, optimism, occupational well-being, innovative behaviors, resourcefulness, and creativity. ${ }^{117,122-125}$ Scholars have stated that employees improve their well-being and job efficiency through personal initiative and reflect positive outcomes. ${ }^{126}$ Moreover, it has been revealed in earlier studies that work engagement, and creative idea generation leads to higher performance and innovation with the utilization of personal initiative. ${ }^{12,124,127}$ Accordingly, this study contends that organizations by providing the environment of HIWPs may enhance EPI level, which may resultantly produce positive outcomes, ie, EIWBs. However, numerous research area remained to be further investigated. For instance, in contrast to the majority of earlier research, which emphasized on the mediating role of workforce perceived control. ${ }^{128,129}$ To the best of our knowledge, there is no research that looked into the mediating role of EPI in the link between HIWPs and EIWBs. The research lacuna is important since a substantial body of existing knowledge indicated that employee initiative is linked to job autonomy, ${ }^{118}$ which, results in positive feelings. ${ }^{130}$ Moreover, scholars ordained that positive 
psychological resources assists to gain positive energies in the form of emotional and physical workload. ${ }^{131}$ As a result, the current study will shed light on the relationship from a new perspective, that of personal initiative. Based on the above discussion, the following hypothesis is proposed:

Hypothesis 3 EPI mediates the positive relationship between HIWPs and EIWBs.

\section{Moderated Mediation Hypothesis}

This integrative model posited that HIWPs could promote EIWBs (Hypothesis 1). We further test the moderating impact of LH on the link between HIWPs and EPI (Hypothesis 2). Additionally, we investigate the mediating impact of EPI in the link between HIWPs and EIWBs (Hypothesis 3). Furthermore, based on the above discussion, we propose a moderated mediation framework in which LH moderates the indirect effect of HIWPs on EIWBs via EPI. Thus, we hypothesize the following:

Hypothesis 4 LH moderates the mediated relationship between HIWPs and EPI in such a way that a higher level of LH will indirectly increase EIWBs in the presence of HIWPs via EPI.

\section{Methodology}

\section{Data Collection, Population, and Sampling}

The target population consisted of officers/supervisors (assistant managers and deputy managers) and line staff (as line staff in the textile industry, directly monitoring the operational work in all sections) working in different sections (ie, quality control, finishing, packing, and production) of various textile industry departments (apparel, knitting, dyeing). In the textile sector, the features of products are systematized with different departments' activities, ${ }^{132}$ which is why different textile sector departments were selected as the population. The researchers contacted the higher management and human resource departments of various textile firms through personal contacts. This sector was selected because the textile industry is the backbone of Pakistan's economy, with earnings of 5.5 billion dollars and a $60-65 \%$ share of the country's economy. ${ }^{133}$ Additionally, this sector holds a $40 \%$ share of employment in the industrial sector in Pakistan. ${ }^{133}$ Furthermore, the textile sector accounts for $60 \%$ of Pakistan's exports ${ }^{134}$ and utilizes $40 \%$ of the nation's workforce. However, these figures do not represent the full potential of the textile sector, ${ }^{132}$ and steps regarding creativity and innovation must be taken to increase its market share in national exports and the worldwide market. ${ }^{133}$

Moreover, Pakistan's textile sector faces challenges and competition ${ }^{134}$ from neighboring and Asian countries such as China, India, Bangladesh, Sri Lanka, Malaysia, and Vietnam, ${ }^{10,135}$ which puts pressure on the management of textile firms to transform the traditional procedures, structures, and systems of production by adopting technological advancement and innovation. ${ }^{136}$ Lack of innovation in the textile sector has become a major challenge as International customers expect high-quality products with reasonable costs. ${ }^{135}$ Given this, Pakistani textile firms cannot survive in global markets without creativity or innovation in production. ${ }^{134,135}$ Moreover, the competencies required for innovation, revolution, and modernization can be attained through redesigning the products and by adopting advanced technologies. ${ }^{137}$ Additionally, scholars have elaborated that utilizing new techniques, structures, and rules is essential, especially when turning products from raw materials into finished goods. ${ }^{138}$ By adopting new techniques and tactics, innovation can be realized in the first stage of product development in the merchandising process and during the conversion of raw material into finished goods. ${ }^{137}$ During the product development process, cooperation among employees ${ }^{139}$ in the form of LH enables them to take personal initiatives to implement new methods and approaches to save time and costs.

Data collection started in January 2020; however, due to the COVID-19 pandemic, questionnaires were circulated via post to the firms' respective human resource departments. The second data collection period started in September 2020 and was late because the Government of Pakistan imposed lockdowns and banned industrial operational activities due to the pandemic. Some questionnaires were circulated through personal visits to some textile firms in September 2020 during the lockdown period in Pakistan, and the industrial sector was fully operational at the direction of the Government of Pakistan. Before data collection, the respondents (both officers/supervisors and staff) were briefed about the research and invited to give their individual opinions. The questionnaires for data collection from management and staff were 
marked with specific codes for accuracy, ease, and matching at the end of the data collection process and further analysis. Each survey was accompanied by a cover letter that described the study's aim, and respondents were assured that the information they provided would remain confidential. Data were collected by random sampling, and the temporal separation (time lag) method was used to overcome common method bias (CMB). ${ }^{140} \mathrm{~A}$ total of two months of temporal separation (time lag) was planned to obtain better responses to the specific questions asked of employees and immediate officers under each variable's heading, ${ }^{140}$ but this was extended from two to four months due to the COVID-19 pandemic. The authors also ran a single factor analysis to test the CMB; the result was $34.49 \%$, which is below the $50 \%$ minimum threshold for the $\mathrm{CMB} .^{141}$

In the first period, the questionnaire for HIWPs (predictor variable) and EPI (mediating variable) were distributed among the participants. In the second period, LH questionnaires (moderating variable) were distributed to the participants who completed the questionnaire in the first period. The EIWBs (criterion variable) questionnaires were rated by subordinates' immediate officers/supervisors. Questionnaires were completed during the second span. Overall, 400 questionnaires were distributed among the staff in the first period, and 310 questionnaires were completed correctly. In the second period, questionnaires regarding LH were circulated to 310 staff who participated in the first lag. Similarly, 153 questionnaires on EIWBs were distributed among officers/supervisors. At the end of the second period, 255 and 119 correctly completed surveys from staff and supervisors, respectively, were collected and finalized. The response rates for staff and officers/supervisors were $82.25 \%$ and $77.77 \%$, respectively, thus constituting a total response rate of $80.01 \%$.

\section{Measurement Scales}

The model consists of four variables (predictor, mediator, moderator, and criterion). The questionnaire consisted of two main parts. The first covered questions about demographic details of the participants, and the second was about the scales, that is, HIWPs, EPI, LH, and EIWBs which were adopted and developed by experienced scholars. The items of all variables were evaluated on a 5 -point Likert scale ranging from $1=$ strongly disagree to $5=$ strongly agree.

\section{High-Involvement Work Practices}

To measure HIWPs, a 21-item scale developed by Wickramasinghe and Gamage ${ }^{76}$ was used following previous studies. ${ }^{66-69}$ Sample items include "In my organization, employees' suggestions are seriously taken into consideration," "In my organization, employees can rotate jobs to develop their skills," and "Employees are regularly informed of technological orientations."

\section{Employees' Personal Initiative}

A nine-item scale developed by Robitschek ${ }^{142}$ was adapted to measure the personal initiative level of staff. Sample items include "I know what I need to do to get started toward reaching my goals" and "I have a specific action plan to help me reach my goals."

\section{Leadership Humility}

A nine-item scale was adapted from Owens et $\mathrm{al}^{42}$ to measure staff's perception of the humility of their immediate officers. Sample items include "My officer/supervisor acknowledges when others have more knowledge and skills than themselves" and "My officer/supervisor shows appreciation for the unique contributions of others."

\section{Employee Innovative Work Behavior}

A six-item scale developed by Scott and Bruce ${ }^{15}$ was used to measure the innovative work behavior level of staff, which was evaluated by their respective leaders. Sample items include "They search out new technologies, processes, techniques, and/or product ideas" and "They investigate and secure funds needed to implement new ideas."

\section{Control Variables}

Demographic variables such as gender, age, education, and experience were controlled as constructs affecting the innovation level of individuals based on different thinking patterns about new ideas in old and young age, ${ }^{4,8}$ 
Similarly, the educational level also influences employees' intellectual level, whereas experienced and fresh employees possess different thinking levels toward the generation of new ideas. ${ }^{14}$

\section{Results}

\section{Analytical Strategy}

SPSS version 25 and Smart-PLS version 3 were utilized for statistical analysis. SPSS is beneficial for statistical analysis, especially in social Sciences. ${ }^{143}$ Additionally, Smart-PLS can be used to rigorously test the complex relationships among variables through different structural models. Moreover, this technique is beneficial for small data samples. ${ }^{144}$

\section{Demographics (Line Staff)}

The authors selected a sample of line staff (quality control, production, finishing, and packing) from the apparel, dyeing, and knitting sections of selected textile firms. The sample included 255 staff, of which $70.98 \%$ (181) were male and $29.02 \%$ (74) were female. A total of 40\% (102 participants) were between the ages of 20-30 years, $46.27 \%$ (118) were between $31-40$ years, $10.59 \%$ (27) were between $41-50$ years, and 3.14\% (8) were between 51-60 years. The majority of the participants possessed a graduate-level qualification (14 years of Schooling, 38.82\% or 99 participants), a master's degree (16 years of schooling, $26.67 \%$ or 68 participants), intermediate (higher secondary schooling, $26.27 \%$ or 67 participants), or M. Phil (18 years of schooling, $2.75 \%$ or 7 participants). In terms of experience, $31.76 \%$ ( 81 participants) had 1-5 years, 27.06\% (69) had 6-10 years, 25.10\% (64) had 11-15 years, $11.37 \%$ (29) had 16-20 years, and $4.71 \%$ (12) had 21 or more years of experience. Such companies also employ individuals with 10-15 years' experience in their respective fields, even with intermediate education, because they hold technical experience; therefore, these individuals are considered beneficial for the organizations.

\section{Demographics (Officers/Supervisors)}

The study included 119 officers/supervisors (assistant managers and deputy managers) who evaluated the innovative work behavior of their subordinates (line staff), of which $73.11 \%$ (87) were male, and 26.89\% (32) were female. A total of $51.26 \%$ (61) of managers were between $20-30$ years old, $31.09 \%$ (37) were between $31-40$, and $17.65 \%$ (21) were between 41-50. A total of 31.09\% (37) held a graduate-level qualification (14 years of schooling), 53.78\% (64) held a master's degree (16 years of schooling), and 15.13\% (18) held an M.Phil. degree (18 years of schooling). A total of $14.29 \%$ (17) had $1-5$ years of experience, $21.85 \%$ (26) had 6-10 years, $37.85 \%$ (45) had $11-15$ years, and 26.05\% (31) had 16-20 years of experience.

\section{Validity and Reliability of Constructs}

The validity of the constructs enhances the extent to which the measurement items fit the theoretical and actual concepts. ${ }^{145}$ Moreover, discriminant validity evaluated the degree to which one latent variable was exactly different from other latent variables. ${ }^{145}$ Convergent validity was used to evaluate whether the variable items account for a significant amount of variance in common and can be evaluated through average variance extracted (AVE) and composite reliability (CR). ${ }^{145}$ Ramayah et al ${ }^{146}$ suggested that if the loading of any item is 0.500 or higher, it can be considered to be a significant loading. The items that did not meet the threshold values were omitted for each variable following this threshold criterion.

Table 1 presents the values of factor loadings and variance inflation factor (VIF); all values of single factor loading meet the minimum threshold $(0.500)$ as recommended by. ${ }^{146}$ On the other hand, the values of VIF also meet the minimum threshold (5-10) as recommended by. ${ }^{147}$ Furthermore, in Table 1, the CR values are according to the threshold $(0.700-0.800)$ suggested by, ${ }^{148}$ and AVE values are also as per the threshold $(0.500)$ recommended by, ${ }^{149}$ which shows that the measurement items of all study variables were reliable. Moreover, the reliability statistics meet the minimum threshold of 0.60 and 0.70 ; Perry et $a^{150}$ suggested that values of reliability between 0.60 to 0.70 are considered moderate. 
Table I Confirmatory Factor Analysis

\begin{tabular}{|c|c|c|c|c|c|c|c|}
\hline Construct & Items & Loadings & VIF & Alpha & Rho_A & CR & AVE \\
\hline HIWPS & $\begin{array}{l}\text { HIWP } 03 \\
\text { HIWP } 05 \\
\text { HIWP } 07 \\
\text { HIWP } 10\end{array}$ & $\begin{array}{l}0.741 \\
0.784 \\
0.827 \\
0.806\end{array}$ & $\begin{array}{l}1.404 \\
1.695 \\
1.926 \\
1.766\end{array}$ & 0.799 & 0.801 & 0.869 & 0.624 \\
\hline EPI & $\begin{array}{l}\text { EPI 0I } \\
\text { EPI } 02 \\
\text { EPI } 04 \\
\text { EPI } 05 \\
\text { EPI } 06 \\
\text { EPI } 07 \\
\text { EPI } 08\end{array}$ & $\begin{array}{l}0.848 \\
0.770 \\
0.670 \\
0.831 \\
0.792 \\
0.756 \\
0.768\end{array}$ & $\begin{array}{l}3.178 \\
2.105 \\
1.551 \\
2.971 \\
2.060 \\
1.839 \\
2.000\end{array}$ & 0.890 & 0.892 & 0.915 & 0.606 \\
\hline LH & $\begin{array}{l}\text { LH } 02 \\
\text { LH } 04 \\
\text { LH } 05 \\
\text { LH } 06 \\
\text { LH } 07 \\
\text { LH } 08 \\
\text { LH } 09\end{array}$ & $\begin{array}{l}0.750 \\
0.765 \\
0.765 \\
0.742 \\
0.708 \\
0.685 \\
0.702\end{array}$ & $\begin{array}{l}1.759 \\
2.912 \\
2.993 \\
1.812 \\
1.980 \\
2.029 \\
1.541\end{array}$ & 0.855 & 0.854 & 0.889 & 0.535 \\
\hline EIWBs & $\begin{array}{l}\text { EIWB } 03 \\
\text { EIWB } 04 \\
\text { EIWB } 05 \\
\text { EIWB } 06\end{array}$ & $\begin{array}{l}0.759 \\
0.836 \\
0.779 \\
0.849\end{array}$ & $\begin{array}{l}1.684 \\
2.349 \\
1.531 \\
2.063\end{array}$ & 0.821 & 0.830 & $0.88 I$ & 0.651 \\
\hline
\end{tabular}

Abbreviations: HIWPs, high involvement work practices; EPI, employees' personal initiative; LH, leadership humility; EIWBs, employee innovative work behaviors; CR, composite reliability; AVE, average variance.

The values of the Fornell and Larker Criterion ${ }^{151}$ are reported in Table 2, where the square root of each AVE value is compared with the bivariate correlational values of all opposing constructs. The top values for all study variables were higher in each column. ${ }^{152}$ Additionally, Table 2 presents the heterotrait-monotrait ratio (HTMT) values, and the values of all variables are less than the threshold of 0.900 , as suggested by. ${ }^{144,153}$ Furthermore, Table 2 reports the values of $f$ square; Cohen ${ }^{154}$ suggested that a value greater or equal to 0.35 is considered to have an exogenous impact on the endogenous variable.

\section{Descriptive Statistics, Q2 Values, and Correlations}

The values of cross-validated redundancy $\left(\mathrm{Q}^{2}\right)$ are reported in Table 3. All values of $\mathrm{Q}^{2}$ are greater than zero, which shows the significance of the model according to the recommendations of, ${ }^{144}$ and there is no issue of blindfolding. The correlation coefficients and descriptive statistics are also presented. The responses were centered around the neutral value of 3 and were also very close, but not the same. Furthermore, the standard deviation values were close to 1 and acceptable. ${ }^{155}$ Recent studies related to the business and management field indicated standard deviation values close to $1 .{ }^{156-158}$ Moreover, bivariate correlation values show that all variables correlate significantly at a significance level of 0.01 .

\section{Path Analysis}

The results of the direct, moderation, indirect, and moderated mediation paths of the relationship are reported in Table 4 . The direct path indicated a significant positive influence of HIWPs on EIWBs $(b=0.139, t=2.849, p<0.004, \mathrm{LL} / \mathrm{UL}=0.061 / .269)$, thus proving hypothesis 1 . To assess the interaction effect, the bootstrapping algorithm method ${ }^{159}$ was used as recommended by ${ }^{144}$ using Smart-PLS to test the interactive effects of LH. Table 4 demonstrates the interactive (HIWPs x LH) influence EPI where $(\beta=0.074, \mathrm{t}=3.259, \mathrm{p}<0.001)$, and there was no zero found between the bias-corrected CIs $(0.118 / 0.031)$; thus, this proves hypothesis 2 . To test the indirect effects of employees' personal initiative, the bootstrapping ${ }^{159}$ algorithm method 
Table 2 Discriminant Validity

\begin{tabular}{|c|c|c|c|c|}
\hline \multirow[t]{2}{*}{ Variables } & \multicolumn{4}{|c|}{ Fornell-Larcker Criterion } \\
\hline & EIWBs & EPC & EPI & HIWPs \\
\hline EIWBs & 0.807 & & & \\
\hline LH & 0.610 & 0.778 & & \\
\hline EPI & 0.432 & 0.549 & 0.790 & \\
\hline HIWPs & 0.677 & 0.726 & 0.681 & 0.732 \\
\hline \multirow[t]{2}{*}{ Variables } & \multicolumn{4}{|c|}{ Heterotrait-Monotrait Ratio (HTMT) } \\
\hline & EIWBs & EPI & HIWPs & LH \\
\hline \multicolumn{5}{|l|}{ EIWBs } \\
\hline EPI & 0.697 & & & \\
\hline HIWPs & 0.514 & 0.830 & & \\
\hline LH & 0.790 & 0.649 & 0.820 & \\
\hline \multirow[t]{2}{*}{ Variables } & \multicolumn{4}{|c|}{$f$ Square Values } \\
\hline & EIWBs & EPC & EPI & HIWPs \\
\hline \multicolumn{5}{|l|}{ EIWBs } \\
\hline LH & 0.203 & & & \\
\hline EPI & 0.318 & & & \\
\hline HIWPs & 0.505 & 0.577 & 0.345 & \\
\hline
\end{tabular}

Abbreviations: HIWPs, high involvement work practices; EPI, employees' personal initiative; LH, leadership humility; EIWBs, employee innovative work behaviors.

Table 3 Descriptive Statistics, $\mathrm{Q}^{2}$ Values and Correlations

\begin{tabular}{|l|l|c|c|c|c|c|c|c|c|c|}
\hline \multicolumn{2}{|l|}{ Variables } & SSO & SSE & Q2 (I-SEE/SSO) & Mean & S.D & I & $\mathbf{2}$ & $\mathbf{3}$ & $\mathbf{4}$ \\
\hline $\mathbf{I}$ & HIWPS & 1020.000 & 776.889 & 0.238 & 3.68 & 0.85466 & & $0.549 * *$ & $0.678^{* *}$ & $0.412^{* *}$ \\
$\mathbf{2}$ & EPI & 1785.000 & 1220.926 & 0.316 & 3.76 & 0.83586 & & & $0.724^{* *}$ & $0.592^{* *}$ \\
$\mathbf{3}$ & LH & 1020.000 & 1020.000 & - & 3.83 & 0.74661 & & & & $0.657^{* *}$ \\
$\mathbf{4}$ & EIWBs & 1785.000 & 1785.000 & - & 3.77 & 0.92724 & & & & \\
\hline
\end{tabular}

Note: $* * p<0.01$

Abbreviations: HIWPs, high involvement work practices; EPI, employees' personal initiative; LH, leadership humility; EIWBs, employee innovative work behaviors.

recommended by ${ }^{144}$ was used. The results demonstrate the indirect impact of EPI between the relationship of HIWPs and EIWBs ( $\beta=0.294, t=5.364, p<0.001)$, and there was no zero found between the bias-corrected CIs $(0.190 / 0.404)$, thus proving hypothesis 3. Finally, the results of moderated mediation effects revealed that $\beta=0.073, t=3.299, p<0.001$, and there was no zero found between the bias-corrected CIs $(0.066 / 0.015)$; thus, this proves hypothesis 4 .

Figure 2 shows the moderation slope, where we found that when the level of HIWPs was high, and the LH was also high, it increased EPI level. In other words, a higher level of LH with a higher level of HIWPs in the workplace increases the level of EPI.

Figure 3 further explains the moderated mediation effect, when interactive effects (HIWPs x LH) on EPI was significant and this moderated relationship also indirectly influences the EIWBs in the presence of HIWPs, which further explains that a higher level of LH and a higher level of HIWPs influence the EIWBs via EPI.

\section{Discussion}

This study investigated the impact of HIWPs on EIWBs through the mediating effect of EPI. Additionally, we examined the moderating role of LH in the relationship between HIWPs and EPI. We also investigated a conceptual framework using the lens of the CTC in the textile industry. 
Table 4 Direct, Indirect, Interactive and Moderated Mediation Analysis

\begin{tabular}{|c|c|c|c|c|c|}
\hline Relationship & $\boldsymbol{\beta}$ & SE & t-Values & p-values & LL/UL \\
\hline \multicolumn{6}{|l|}{ Direct Effects } \\
\hline HIWPs $\rightarrow$ EIWBs & 0.139 & 0.07 & 2.849 & 0.004 & $0.061 / .269$ \\
\hline \multicolumn{6}{|l|}{ Indirect Effects } \\
\hline HIWPs $\rightarrow$ EPI $\rightarrow$ EIWBs & 0.294 & 0.06 & 5.364 & 000 & $0.190 / .404$ \\
\hline \multicolumn{6}{|l|}{ Interactive Effects } \\
\hline HIWPs $\times$ LH $\rightarrow$ EPI & 0.074 & 0.02 & 3.259 & 0.001 & $0.118 / .031$ \\
\hline \multicolumn{6}{|l|}{ Moderated Mediation Effects } \\
\hline HIWPs $\times$ LH $\rightarrow$ EPI $\rightarrow$ EIWBs & 0.073 & 0.01 & 3.299 & 0.001 & $0.066 / .015$ \\
\hline
\end{tabular}

Note: Bootstrap sample size $=5000$.

Abbreviations: HIWPs, high involvement work practices; EPI, employees' personal initiative; LH, leadership humility; EIWBs, employee innovative work behaviors.

Generally, the findings support the proposed hypotheses, as hypothesis 1 posited a positive impact of HIWPs (ie, empowerment, communication, recognition, reward, skill development, and performance evaluation) on EIWBs. We found significant results that were consistent with. ${ }^{4,77,78}$ Correspondingly, the CTC stresses the significance of personal capabilities and inner inspiration. ${ }^{16,51}$ Therefore, HIWPs comprise a set of positive skills that increase EIWBs. Hypothesis 2 predicted that LH moderates the relationship between HIWPs and EPI, and the findings also provide evidence for the acceptance of this hypothesis. The findings also explained that a higher level of LH increases the level of EPI in the presence of high HIWPs. Previous studies also provide significant support for the results of the current study. ${ }^{115,160}$ Similarly, CTC stated the importance of motivation and a supportive environment of the organization's innovation and creativity ${ }^{16,51}$ as LH serve as motivation through teachability and encourage their subordinates to take opportunities and risks to solve critical problems, which enables them to generate and implement new ideas. ${ }^{42,43,108,161}$ Despite evidence of a direct connection, the current research followed a contingency approach and examined a significant personal component, that is, EPI, which affects the relationship between HIWPs and EIWBs. Thus, the findings support the mediating role of EPI in line with. ${ }^{118,127,162}$ The results confirmed that HIWPs are the essential intrinsic and extrinsic motivation factors that boost EPI levels, leading to the generation and sharing of novel ideas/thinking. In particular, it is suggested that EPI at work is vital to ensure that HIWPs have the intended effect on EIWBs. Accordingly, CTC also elaborated that when there is a gain of positive resources such as

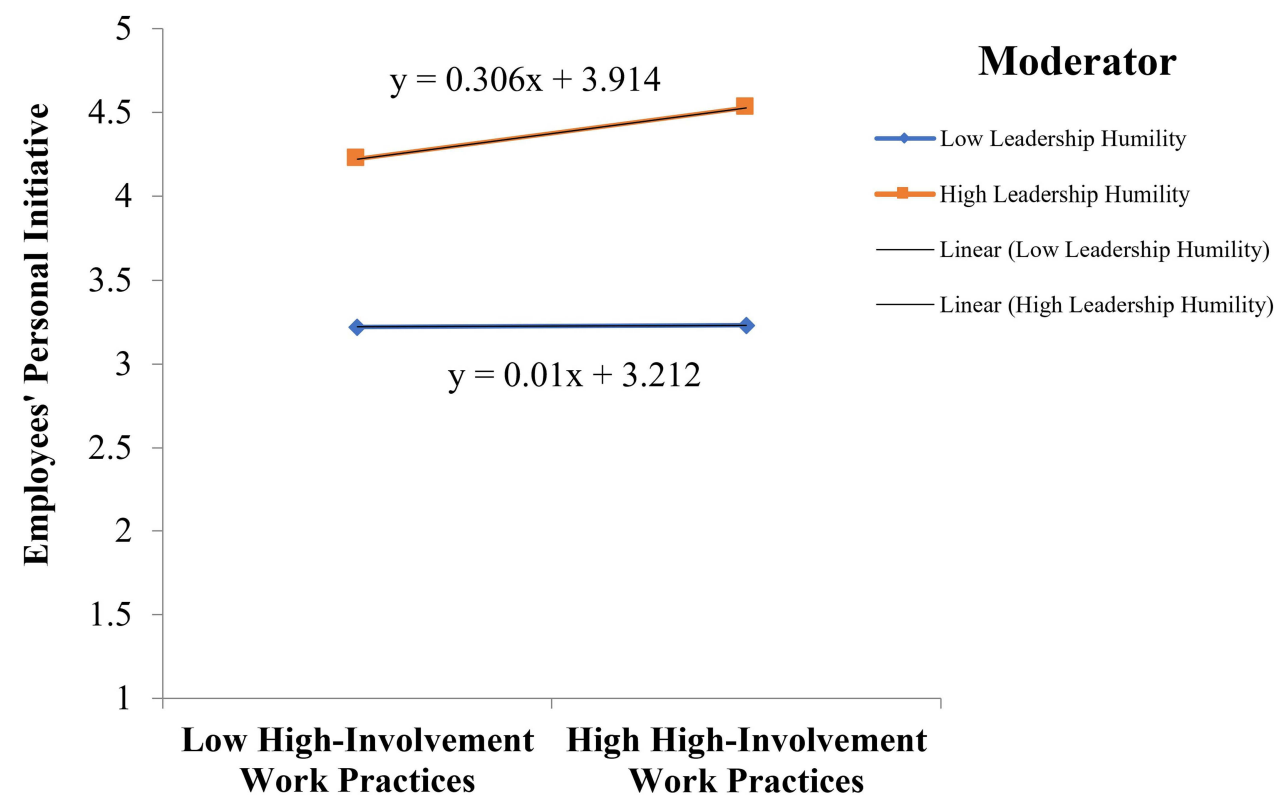

Figure 2 The interaction effect of Leadership Humility on the relationship between High Involvement Work Practices and Employees Personal Initiative. 


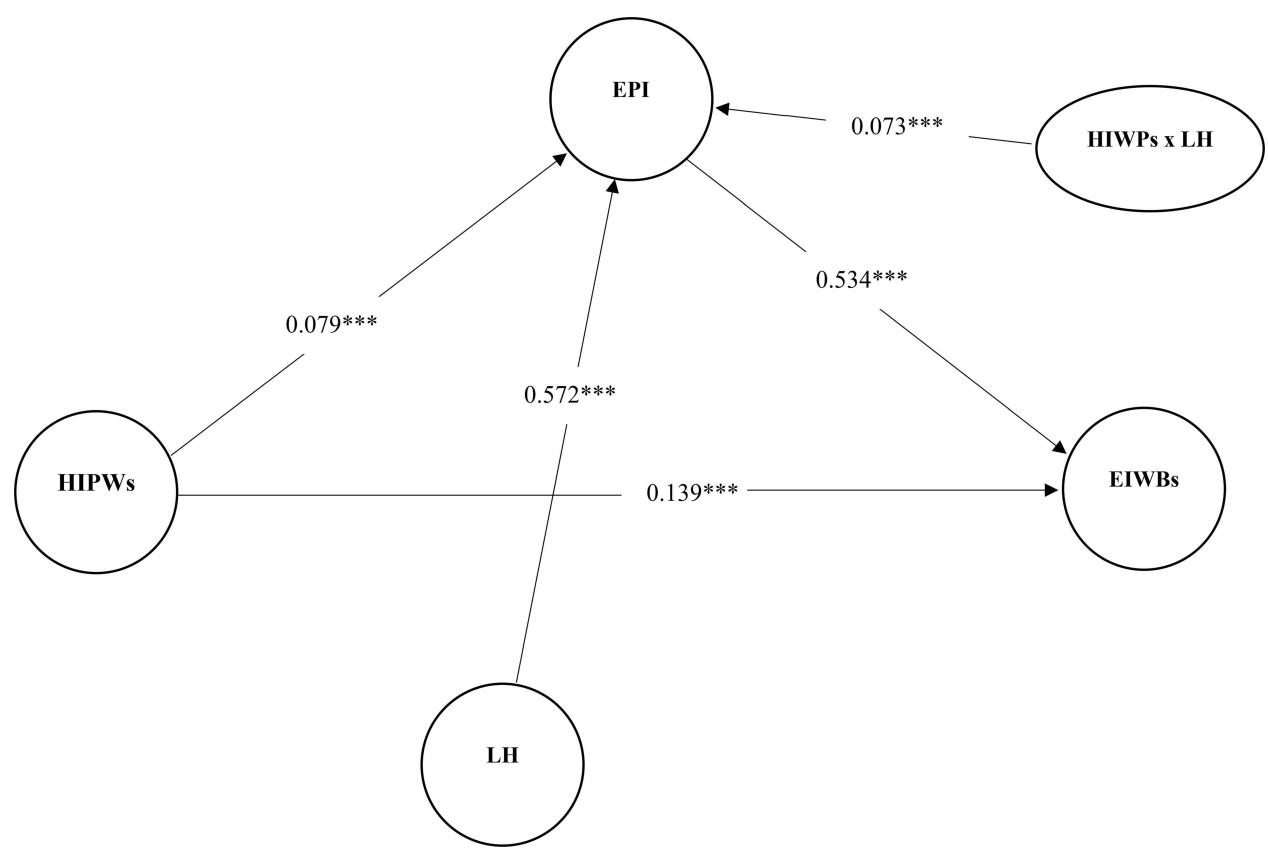

Figure 3 The structural equation modelling of moderated mediation. Note: $* * * P<0.001$.

EPI, which is a key resource for developing skills (ie, derived from HIWPs) resulting in EIWBs. Hypothesis 4, which focuses on the moderated mediation model, predicted that LH moderates the indirect influence of HIWPs on EIWBs via EPI. The findings demonstrated that a higher level of LH provides motivation and a supportive environment for employees that enhances their level of EPI in the presence of HIWPs, which provide intrinsic and extrinsic motivation that increase EIWBs.

\section{Theoretical Implications}

The findings contribute to the literature on human resource management and organizational behavior, especially in the textile industry. First, the findings revealed a positive and significant impact of HIWPs on EIWBs. The current research suggests that organizations invest in humans through HIWPs (ie, empowerment, communication, recognition, reward, skill development, and performance evaluation) to attain EIWBs. Additionally, this study examined the moderating role of LH, as for any organizational success, the need for leadership in any era is imperative. The findings demonstrated that LH not only provides a positive social and organizational environment but also encourages their subordinates through training to take risks and initiatives for the solution of complex problems; these leaders also hold the quality of accepting criticism and learning from others. ${ }^{42,43,161}$ This study extends this model by investigating the mediation of EPI in the association between HIWPs and EIWBs. For the growth and improvement of an organization, EPI serves as a major personal source that plays a vital role in the link between HIWPs (ie, empowerment, communication, recognition, reward, skill development, and performance evaluation) EIWBs in the workplace.

According to CTC, the process of innovation and creativity is influenced by cognitive ability, motivation, and the social and organizational environment. We, therefore, argue that HIWPs provide the motivation that enhances the cognitive ability level of employees in the form of personal initiative with the support of social and organizational environments such as LH, which promotes creativity and innovation. ${ }^{16,62}$ Further, by incorporating CTC, this study contributes to the literature by identifying HIWPs, that is, communication, empowerment as domain-related skills, and performance evaluation as organizational environment, recognition, and skill development as factors of intrinsic motivation and reward as extrinsic motivation that cultivates positive behaviors, such as EIWBs. 


\section{Practical Implications}

Our findings have several implications that validate the importance of HIWPs in enhancing EIWBs, especially for the line staff of the manufacturing sector (textile). For the attainment of the innovative and creative production of services, management must provide guidance on the job and assistance to employees about how they can utilize the HIWPs (ie, empowerment, communication, recognition, reward, skill development, and performance evaluation) for the formation and sharing of innovative and creative ideas, especially in the manufacturing sector, which further becomes beneficial during the production process of quality goods, thereby enabling organizations to achieve and sustain competitive advantage. Higher management of organizations from the manufacturing sector (textile) also concentrates on line staffs' awareness to overcome uncertainty and stress in the workplace through verbal motivation to produce more positive and innovative outcomes, as this manufacturing sector is much more sensitive, where outcomes of line staff not only directly affect the cost and production process but also the production quality. Moreover, manufacturing sector industries, especially textile, can also benefit by implementing HIWPs, that is, flexible working procedures ${ }^{163}$ that would facilitate innovative productivity at the individual and institutional levels. As our findings demonstrate that EPI is an essential factor for innovative productivity, management of the manufacturing sector industries makes policies and strategies toward fast, active planning, information sharing, and feedback, which not only triggers the degree of EPI but also enhances the individual's inventiveness. Finally, industries related to the manufacturing sector could arrange workshops and training sessions to raise their management/leadership awareness regarding humility. By using this management tool, management/leadership can learn how they can motivate and encourage their workforce to utilize opportunities. The manufacturing sector is the key sector of the economy of every nation, and there is no chance of risk, and higher productive services can be achieved with the utilization of motivation by management/leadership.

\section{Limitations, and Future Research}

The present study has the following limitations. First, the data were collected from the manufacturing sector (textile); researchers may replicate our findings in different sectors (eg, information technology, service, and public sector). Second, this study investigated the influence of HIWPs on EIWBs through the mediating effects of EPI, and future research could also explore the impact of HIWPs with other mediators, such as personality traits, resilience, and selfefficacy ${ }^{80}$ with different negative and positive behavioral outcomes. Third, we used LH as a positive moderator and encouraged future researchers to investigate the negative aspects of humble leaders ${ }^{98}$ and the influence of other positive leadership styles as moderators. Lastly, we controlled for demographics (gender, age, education, experience); future research can investigate the impact of gender and experience on HIWPs with other positive/negative outcomes.

\section{Ethics Statement}

This study was carried out following the recommendations of the Ethical Principles of Psychologists and Code of Conduct by the American Psychological Association (APA). All participants gave written informed consent following the Declaration of Helsinki. The ethics committee approved the protocol of International Islamic University, Pakistan.

\section{Author Contributions}

All authors made a significant contribution to the work reported, whether that is in the conception, study design, execution, acquisition of data, analysis and interpretation, or in all these areas; took part in drafting, revising, or critically reviewing the article; gave final approval of the version to be published; have agreed on the journal to which the article has been submitted; and agree to be accountable for all aspects of the work.

\section{Funding}

This study was supported by National Natural Science Foundation of China (71573109 and 71974082). 


\section{Disclosure}

The authors report no conflicts of interest for this work and declare that the research was conducted without any commercial or financial relationships that could be construed as a potential conflict of interest.

\section{References}

1. Zhiqiang M, Khan HS, Chughtai MS, Mingxing L. Re-engineering the human resource strategies amid and post-pandemic crisis: probing into the moderated mediation model of the high-performance work practices and employee's outcomes. Front Psychol. 2021;12:1-10. doi:10.3389/ fpsyg.2021.710266

2. Akram T, Lei S, Haider MJ. The impact of relational leadership on employee innovative work behavior in IT industry of China. Arab Econ and Bus J. 2016;11(2):153-161. doi:10.1016/j.aebj.2016.06.001

3. Lányi B. The influence of personality traits of start-up entrepreneurs on the innovative market presence in the medical biotechnology and health care industry. Paper presented at: Marketing From Information to Decision; 2016.

4. Liu Y, Xu S, Zhang B. Thriving at work: how a paradox mindset influences innovative work behavior. J Appl Behav Sci. 2020;56(3):347-366. doi: $10.1177 / 0021886319888267$

5. Knezović E, Drkić A. Innovative work behavior in SMEs: the role of transformational leadership. Empl Relat. 2020;43:398-415. doi:10.1108/ ER-03-2020-0124

6. Afsar B, Al-Ghazali BM, Cheema S, Javed F. Cultural intelligence and innovative work behavior: the role of work engagement and interpersonal trust. Eur J Innov Manag. 2020. doi:10.1108/EJIM-01-2020-0008

7. Cangialosi N, Odoardi C, Battistelli A. Learning climate and innovative work behavior, the mediating role of the learning potential of the workplace. Vocat Learn. 2020;13:263-280.

8. Odoardi C, Montani F, Boudrias J-S, Battistelli A. Linking managerial practices and leadership style to innovative work behavior. Leadersh Organ Dev J. 2015;36(5):545-569. doi:10.1108/LODJ-10-2013-0131

9. Newman A, Neesham C, Manville G, Tse HH. Examining the influence of servant and entrepreneurial leadership on the work outcomes of employees in social enterprises. Int J Hum Resour Manag. 2018;29(20):2905-2926. doi:10.1080/09585192.2017.1359792

10. Padilha CK, Gomes G. Innovation culture and performance in innovation of products and processes: a study in companies of textile industry. RAI Revista de Administração e Inovação. 2016;13(4):285-294. doi:10.1016/j.rai.2016.09.004

11. Lukes M, Stephan U. Measuring employee innovation: a review of existing scales and the development of the innovative behavior and innovation support inventories across cultures. Int J Entrepreneurial Behav Res. 2017;23(1):136-158. doi:10.1108/IJEBR-11-2015-0262

12. KhanHS, Zhiqiang M, Siddiqui SH, Khan MAS. Be aware not reactive: testing a mediated-moderation model of dark triad and perceived victimization via self-regulatory approach. Front Psychol. 2020;11:2141. doi:10.3389/fpsyg.2020.02141

13. Khan HS, Zhiqiang M, Musah -A-AI, Udimal TB. Impact of perceived organisational politics on job attitudes in health sector of Pakistan: the moderating role of Islamic work ethic. Middle East J Manag. 2019;6(6):767-791. doi:10.1504/MEJM.2019.102842

14. West MA, Farr JL. Innovation at work. In: West MA, Farr JL, editors. Innovation and Creativity at Work: Psycological and Organizational Strategies. New York: John Wiley; 1990:3-13.

15. Scott SG, Bruce RA. Determinants of innovative behavior: a path model of individual innovation in the workplace. Acad Manag Ann. 1994;37 (3):580-607.

16. Amabile TM. A model of creativity and innovation in organizations. Res Organ Behav. 1988;10(1):123-167.

17. Wang Z, Gao M, Panaccio A. A self-determination approach to understanding individual values as an interaction condition on employees' innovative work behavior in the high-tech industry. J Creat Behav. 2021;55(1):183-198. doi:10.1002/jocb.444

18. Afsar B, Masood M, Umrani WA. The role of job crafting and knowledge sharing on the effect of transformational leadership on innovative work behavior. Pers Rev. 2019;48(5):1186-1208. doi:10.1108/PR-04-2018-0133

19. Eide AE, Saether EA, Aspelund A. An investigation of leaders' motivation, intellectual leadership, and sustainability strategy in relation to Norwegian manufacturers' performance. J Clean Prod. 2020;254:120053. doi:10.1016/j.jclepro.2020.120053

20. Riana IG, Suparna G, Suwandana IGM, Kot S, Rajiani I. Human resource management in promoting innovation and organizational performance. Probl Perspect Manag. 2020;18(1):107. doi:10.21511/ppm.18(1).2020.10

21. Jensen JM, Patel PC, Messersmith JG. High-performance work systems and job control: consequences for anxiety, role overload, and turnover intentions. J Manage. 2013;39(6):1699-1724. doi:10.1177/0149206311419663

22. Alikaj A, Ning W, Wu B. Proactive personality and creative behavior: examining the role of thriving at work and high-involvement HR practices. J Bus Psychol. 2020;36:857-869.

23. Chen M, Wang J. The influence of high-involvement human resources practices on proactive behavior. Paper presented at: E3S Web of Conferences; 2021.

24. Lawler E. Far from the fad in-crowd: research on employee involvement and total quality management. People Manag. 1996;2(21):38-40.

25. Pfeffer J, Veiga JF. Putting people first for organizational success. Acad Manag Exec. 1999;13(2):37-48.

26. Patterson MG, West MA, Wall TD. Integrated manufacturing, empowerment, and company performance. J Organ Behav. 2004;25(5):641-665. doi:10.1002/job.261

27. Song Z, Gu Q, Cooke FL. The effects of high-involvement work systems and shared leadership on team creativity: a multilevel investigation. Hum Resour Manage. 2020;59(2):201-213. doi:10.1002/hrm.21988

28. Boxall P, Hutchison A, Wassenaar B. How do high-involvement work processes influence employee outcomes? An examination of the mediating roles of skill utilisation and intrinsic motivation. Int $J$ Hum Resour Manag. 2015;26(13):1737-1752. doi:10.1080/ 09585192.2014.962070

29. Prieto IM, Pérez-Santana MP. Managing innovative work behavior: the role of human resource practices. Pers Rev. 2014;43(2):184-208. doi:10.1108/PR-11-2012-0199

30. Tamunomiebi A, Barasin E. Organizational trustworthiness and employee innovative work behaviour. Glob J Manag Bus Res. 2020;20 (3):16-23. 
31. Appelbaum E, Bailey T, Berg P, Kalleberg AL, Bailey TA. Manufacturing Advantage: Why High-Performance Work Systems Pay Off. Ithaca: NY Cornell University Press; 2000.

32. Edwards P, Wright M. High-involvement work systems and performance outcomes: the strength of variable, contingent and context-bound relationships. Int J Human Res Manag. 2001;12(4):568-585. doi:10.1080/713769651

33. Lawler EE. High-Involvement Management. 1st ed. San Francisco, Calif: Jossey-Bass; 1986.

34. Riordan CM, Vandenberg RJ, Richardson HA. Employee involvement climate and organizational effectiveness. Hum Resour Manage. 2005;44 (4):471-488. doi:10.1002/hrm.20085

35. Bae J, Lawler JJ. Organizational and HRM strategies in Korea: impact on firm performance in an emerging economy. Acad Manage J. 2000;43 (3):502-517.

36. Shin SJ, Jeong I, Bae J. Do high-involvement HRM practices matter for worker creativity? A cross-level approach. Int J Hum Resour Manag. 2018;29(2):260-285. doi:10.1080/09585192.2015.1137612

37. Bledow R, Frese M. A situational judgment test of personal initiative and its relationship to performance. Pers Psychol. 2009;62(2):229-258. doi:10.1111/j.1744-6570.2009.01137.x

38. Frese M, Kring W, Soose A, Zempel J. Personal initiative at work: differences between East and West Germany. Acad Manag Ann. 1996;39 (1):37-63.

39. Frese M, Fay D. Personal initiative: an active performance concept for work in the 21st century. Res Organ Behav. 2001;23:133-187. doi:10.1016/S0191-3085(01)23005-6

40. Mallén F, Domínguez-Escrig E, Lapiedra R, Chiva R. Does leader humility matter? Effects on altruism and innovation. Manag Decis. 2019;58 (5):967-981. doi:10.1108/MD-11-2018-1180

41. Zhou F, Wu YJ. How humble leadership fosters employee innovation behavior. Leadersh Organ Dev J. 2018;39(3):375-387. doi:10.1108/ LODJ-07-2017-0181

42. Owens BP, Johnson MD, Mitchell TR. Expressed humility in organizations: implications for performance, teams, and leadership. Organ Sci. 2013;24(5):1517-1538. doi:10.1287/orsc.1120.0795

43. Owens BP, Hekman DR. Modeling how to grow: an inductive examination of humble leader behaviors, contingencies, and outcomes. Acad Manag Ann. 2012;55(4):787-818. doi:10.5465/amj.2010.0441

44. Kalina P. "Humble, hungry and smart?" A cautionary tale for inclusive healthcare leaders. Int J Health Plann Manag. 2020;35(5):1267-1269. doi: $10.1002 / \mathrm{hpm} .2990$

45. Naqshbandi MM, Tabche I. The interplay of leadership, absorptive capacity, and organizational learning culture in open innovation: testing a moderated mediation model. Technol Forecast Soc Change. 2018;133:156-167. doi:10.1016/j.techfore.2018.03.017

46. Frese M, Garst H, Fay D. Making things happen: reciprocal relationships between work characteristics and personal initiative in a four-wave longitudinal structural equation model. J Appl Psychol. 2007;92(4):1084-1102. doi:10.1037/0021-9010.92.4.1084

47. Schraub EM, Michel A, Shemla M, Sonntag K. The roles of leader emotion management and team conflict for team members' personal initiative: a multilevel perspective. Eur J Work Organ Psychol. 2014;23(2):263-276. doi:10.1080/1359432X.2012.728700

48. Ohly S, Sonnentag S, Pluntke F. Routinization, work characteristics and their relationships with creative and proactive behaviors. $J$ Organ Behav. 2006;27(3):257-279. doi:10.1002/job.376

49. Sonnentag S. Recovery, work engagement, and proactive behavior: a new look at the interface between nonwork and work. J Appl Psychol. 2003;88(3):518-528. doi:10.1037/0021-9010.88.3.518

50. Lisbona A, Las-Hayas A, Palací FJ, Bernabé M, Morales FJ, Haslam A. Team efficiency in organizations: a group perspective on initiative. Int J Environ Res Public Health. 2020;17(6):1926. doi:10.3390/ijerph17061926

51. Amabile TM. The social psychology of creativity: a componential conceptualization. J Pers Soc Psychol. 1983;45(2):357-376. doi:10.1037/ 0022-3514.45.2.357

52. Amabile TM. Motivating creativity in organizations: on doing what you love and loving what you do. Calif Manage Rev. 1997;40(1):39-58. doi:10.2307/41165921

53. Amabile TM, Conti R. Changes in the work environment for creativity during downsizing. Acad Manag Ann. 1999;42(6):630-640.

54. Amabile TM, Schatzel EA, Moneta GB, Kramer SJ. Leader behaviors and the work environment for creativity: perceived leader support. Leadersh Q. 2004;15(1):5-32. doi:10.1016/j.leaqua.2003.12.003

55. Amabile TM, Conti R, Coon H, Lazenby J, Herron M. Assessing the work environment for creativity. Acad Manag Ann. 1996;39:5.

56. Boxall P, Huo M-L, Macky K, Winterton J. High-involvement work processes and systems: a review of theory, distribution, outcomes, and tensions. Res Pers Hum Resour Manag. 2019;37:1-52.

57. Kee DMH, Rubel MRB. Technology adaptation is on its way: the role of high involvement work practice. Int J Bus Innov Res. 2021;25 (1):35-50. doi:10.1504/IJBIR.2021.115011

58. Boxall P, Huo ML. Fostering the high-involvement model of human resource management: what have we learnt and what challenges do we face? Asia Pac J Hum Resour. 2021. doi:10.1111/1744-7941.12305

59. Ahmad M, Allen MMC, Raziq MM, Ur Rehman W. Converging HRM practices? A comparison of high performance work system practices in MNC subsidiaries and domestic firms in Pakistan. Empl Relat. 2019;41(5):931-948. doi:10.1108/ER-01-2018-0021

60. Yasir M, Majid A. High-involvement HRM practices and innovative work behavior among production-line workers: mediating role of employee's functional flexibility. Empl Relat. 2020;42(4):883-902. doi:10.1108/ER-02-2018-0061

61. Farrukh M, Ansari NY, Raza A, Meng F, Wang H. High-performance work practices do much, but HERO does more: an empirical investigation of employees' innovative behavior from the hospitality industry. Eur J Innov Manag. 2021. doi:10.1108/EJIM-11-2020-0448

62. Amabile TM, Pillemer J. Perspectives on the social psychology of creativity. $J$ Creat Behav. 2012;46(1):3-15.

63. Hong Y, Liao H, Raub S, Han JH. What it takes to get proactive: an integrative multilevel model of the antecedents of personal initiative. $J$ Appl Psychol. 2016;101(5):687-701. doi:10.1037/ap10000064

64. Guthrie JP. High-involvement work practices, turnover, and productivity: evidence from New Zealand. Acad Manag J. 2001;44(1):180-190.

65. Collins CJ, Smith KG. Knowledge exchange and combination: the role of human resource practices in the performance of high-technology firms. Acad Manage J. 2006;49(3):544-560. doi:10.5465/amj.2006.21794671 
66. Blackburn R, Rosen B. Total quality and human resources management: lessons learned from Baldrige Award-winning companies. Acad Manag Perspect. 1993;7(3):49-66. doi:10.5465/ame.1993.9411302347

67. Bou JC, Beltrán I. Total quality management, high-commitment human resource strategy and firm performance: an empirical study. Total Qual Manag Bus Excell. 2005;16(1):71-86. doi:10.1080/1478336042000309875

68. Lawler EE. From job-based to competency-based organizations. J Organ Behav. 1994;15(1):3-15. doi:10.1002/job.4030150103

69. Sun L-Y, Aryee S, Law KS. High-performance human resource practices, citizenship behavior, and organizational performance: a relational perspective. Acad Manag Ann. 2007;50(3):558-577. doi:10.5465/amj.2007.25525821

70. Paré G, Tremblay M. The influence of high-involvement human resources practices, procedural justice, organizational commitment, and citizenship behaviors on information technology professionals' turnover intentions. Group Organ Manag. 2007;32(3):326-357. doi:10.1177/ 1059601106286875

71. Vazquez-Bustelo D, Avella L. The effectiveness of high-involvement work practices in manufacturing firms: does context matter? J Manag Organ. 2019;25(2):303-330. doi:10.1017/jmo.2016.69

72. Tsai C-T, Tseng WW. A research agenda of transformational leadership and innovative behavior for the hospitality industry: an integrated multilevel model. Paper presented at: In Annual International Council on Hotels Restaurants and Institutional Education Conference; 2010.

73. Amabile TM, Barsade SG, Mueller JS, Staw BM. Affect and creativity at work. Adm Sci Q. 2005;50(3):367-403. doi:10.2189/ asqu.2005.50.3.367

74. De Jong J, Den Hartog D. Measuring innovative work behaviour. Creativity Innov Manag. 2010;19(1):23-36. doi:10.1111/j.14678691.2010.00547.x

75. Yuan F, Woodman RW. Innovative behavior in the workplace: the role of performance and image outcome expectations. Acad Manag Ann. 2010;53:323-342. doi:10.5465/amj.2010.49388995

76. Wickramasinghe V, Gamage A. High-involvement work practices, quality results, and the role of HR function. TQM J. 2011;23(5):516-530. doi:10.1108/17542731111157626

77. Dong Y, Bartol KM, Zhang ZX, Li C. Enhancing employee creativity via individual skill development and team knowledge sharing: influences of dual-focused transformational leadership. J Organ Behav. 2017;38(3):439-458. doi:10.1002/job.2134

78. Van Esch E, Wei LQ, Chiang FF. High-performance human resource practices and firm performance: the mediating role of employees' competencies and the moderating role of climate for creativity. Int J Hum Resour Manag. 2018;29(10):1683-1708. doi:10.1080/ 09585192.2016 .1206031

79. Afshan G, Kashif M, Khanum F, Khuhro MA, Akram U. High involvement work practices often lead to burnout, but thanks to humble leadership. J Manag Dev. 2021;40(6):503-525. doi:10.1108/JMD-10-2020-0311

80. Kilroy S, Bosak J, Flood PC, Peccei R. Time to recover: the moderating role of psychological detachment in the link between perceptions of high-involvement work practices and burnout. J Bus Res. 2020;108:52-61. doi:10.1016/j.jbusres.2019.10.012

81. Song W, Yu H, Qu Q. High involvement work systems and organizational performance: the role of knowledge combination capability and interaction orientation. Int J Hum Resour Manag. 2021;32(7):1566-1590. doi:10.1080/09585192.2018.1539863

82. Färber AS, Nazneen Islam R. Information and communication technology professionals' perceptions of high-involvement work practices and their work engagement-an investigation of the roles of work-life balance and psychological job demands. Department of Sociology and Work Science, University of Gothenburg; 2021.

83. Maden C. Linking high involvement human resource practices to employee proactivity. Pers Rev. 2015;44(5):720-738. doi:10.1108/PR-012014-0030

84. Macky K, Boxall P. High-involvement work processes, work intensification and employee well-being: a study of New Zealand worker experiences. Asia Pac J Hum Resour. 2008;46(1):38-55. doi:10.1177/1038411107086542.

85. Garmendia A, Elorza U, Aritzeta A, Madinabeitia-Olabarria D. High-involvement HRM, job satisfaction and productivity: a two wave longitudinal study of a Spanish retail company. Hum Resour Manag J. 2021;31(1):341-357. doi:10.1111/1748-8583.12307

86. Turner T, Cross C. Do high-involvement work practices affect employee earnings in union and non-union settings in the Irish private sector? Pers Rev. 2018;47(2):425-440. doi:10.1108/PR-10-2016-0269

87. Li H, Jin H, Chen T. Linking proactive personality to creative performance: the role of job crafting and high-involvement work systems. $J$ Creat Behav. 2020;54(1):196-210. doi:10.1002/jocb.355

88. Tremblay M. How, why, and when high-involvement work systems are related to OCB: a multilevel examination of the mediating role of POS and of the moderating role of organizational structures. Group Organ Manag. 2019;44(3):611-651. doi:10.1177/1059601117736684

89. Wang X, Zhang Z, Chun D. How does mobile workplace stress affect employee innovative behavior? The role of work-family conflict and employee engagement. Behav Sci. 2022;12(1):1-13.

90. Vranjes I, Notelaers G, Salin D. Putting workplace bullying in context: the role of high-involvement work practices in the relationship between job demands, job resources, and bullying exposure. J Occup Health Psychol. 2021. doi:10.1037/ocp0000315

91. Kilroy S, Bosak J, Chênevert D, Flood PC, Hill K. Reducing burnout among nurses: the role of high-involvement work practices and colleague support. Health Care Manage Rev. 2021. doi:10.1097/HMR.0000000000000304

92. Kilroy S, Flood PC, Bosak J, Chênevert D. Perceptions of high-involvement work practices and burnout: the mediating role of job demands. Hum Resour Manag J. 2016;26(4):408-424. doi:10.1111/1748-8583.12112

93. Kilroy S, Flood PC, Bosak J, Chênevert D. Perceptions of high-involvement work practices, person-organization fit, and burnout: a time-lagged study of health care employees. Hum Resour Manage. 2017;56(5):821-835. doi:10.1002/hrm.21803

94. Manzoor SR, Khalil Ur Rahman M. The effect of high involvement work system on employee counterproductive work behavior: a mediating role of psychological capital. NICE Res J. 2021:86-106. doi:10.51239/nrjss.v14i1.259

95. Li Y, Wang M, Van Jaarsveld DD, Lee GK, Ma DG. From employee-experienced high-involvement work system to innovation: an emergence-based human resource management framework. Acad Manag Ann. 2018;61(5):2000-2019. doi:10.5465/amj.2015.1101

96. Gupta V, Singh S. Leadership and creative performance behaviors in R\&D laboratories: examining the mediating role of justice perceptions. J Leadersh Organ Stud. 2015;22(1):21-36. doi:10.1177/1548051813517002

97. Caldwell C, Ichiho R, Anderson V. Understanding level 5 leaders: the ethical perspectives of leadership humility. $J$ Manag Dev. 2017;36 (5):724-732. doi:10.1108/JMD-09-2016-0184 
98. Ou AY, Tsui AS, Kinicki AJ, Waldman DA, Xiao Z, Song LJ. Humble chief executive officers' connections to top management team integration and middle managers' responses. Adm Sci Q. 2014;59(1):34-72. doi:10.1177/0001839213520131

99. Qin X, Chen C, Yam KC, Huang M, Ju D. The double-edged sword of leader humility: investigating when and why leader humility promotes versus inhibits subordinate deviance. J Appl Psychol. 2020;105(7):693-714. doi:10.1037/ap10000456

100. Zapata CP, Hayes-Jones LC. The consequences of humility for leaders: a double-edged sword. Organ Behav Hum Decis Process. 2019;152:47-63. doi:10.1016/j.obhdp.2019.01.006

101. Abele AE, Cuddy AJ, Judd CM, Yzerbyt VY. Fundamental Dimensions of Social Judgment. Vol. 38. Chichester, UK: John Wiley \& Sons, Ltd; 2008:1063-1065.

102. Jiang H, Liu W, Jia L. How humble leadership influences the innovation of technology standards: a moderated mediation model. Sustainability. 2019;11(19):5448. doi:10.3390/su11195448

103. Jeung C-W, Yoon HJ. Leader humility and psychological empowerment: investigating contingencies. J Manag Psychol. 2016;31(7):1122-1136. doi:10.1108/JMP-07-2015-0270

104. Chen Y, Liu B, Zhang L, Qian S. Can leader "humility" spark employee "proactivity"? The mediating role of psychological empowerment. Leadersh Organ Dev J. 2018;39(3):326-339. doi:10.1108/LODJ-10-2017-0307

105. Zhang Z, Song P. Multi-level effects of humble leadership on employees' work well-being: the roles of psychological safety and error management climate. Front Psychol. 2020;11:3150. doi:10.3389/fpsyg.2020.571840

106. Zhu Y, Zhang S, Shen Y. Humble leadership and employee resilience: exploring the mediating mechanism of work-related promotion focus and perceived insider identity. Front Psychol. 2019;10:673. doi:10.3389/fpsyg.2019.00673

107. Chen C, Feng J, Liu X, Yao J. Leader humility, team job crafting and team creativity: the moderating role of leader-leader exchange. Hum Resour Manag J. 2021;31(1):326-340. doi:10.1111/1748-8583.12306

108. Wang L, Owens BP, Li JJ, Shi L. Exploring the affective impact, boundary conditions, and antecedents of leader humility. J Appl Psychol. 2018;103(9):1019-1038. doi:10.1037/ap10000314

109. Wang Y, Luo W, Zhang J, Guo Y. More humility, less counterproductive work behaviors? The role of interpersonal justice and trust. Front Bus Res China. 2019;13(1):1-18. doi:10.1186/s11782-019-0069-7

110. Doucet O, Lapalme M-È, Simard G, Tremblay M. High involvement management practices as leadership enhancers. Int J Manpow. 2015;36 (7):1058-1071. doi:10.1108/IJM-10-2013-0243

111. Chiu C-Y, Balkundi P, Owens BP, Tesluk PE. Shaping positive and negative ties to improve team effectiveness: the roles of leader humility and team helping norms. Hum Relat. 2020:0018726720968135. doi:10.1177/0018726720968135

112. Binnewies C, Gromer M. Creativity and innovation at work: the role of work characteristics and personal initiative. Psicothema. 2012;24 (1):100-105.

113. Ali M, Zhang L, Zhang Z, et al. Can leaders' humility enhance project management effectiveness? Interactive effect of top management support. Sustainability. 2021;13(17):9526. doi:10.3390/su13179526

114. Chiu C-YC, Owens BP, Tesluk PE. Initiating and utilizing shared leadership in teams: the role of leader humility, team proactive personality, and team performance capability. J Appl Psychol. 2016;101(12):1705-1720. doi:10.1037/apl0000159

115. Ma C, Ganegoda DB, Chen ZX, Jiang X, Dong C. Effects of perceived overqualification on career distress and career planning: mediating role of career identity and moderating role of leader humility. Hum Resour Manage. 2020;59(6):521-536. doi:10.1002/hrm.22009

116. Khan HS, Zhiqiang M, Musah AAI, Antwi HA, Sarpong PB. Pompous narcissism predicts ethical behaviours at workplace: the moderating role of emotional intelligence. Am J Multidiscip Res. 2017;5(2):1-11.

117. Rooks G, Sserwanga A, Frese M. Unpacking the personal initiative-performance relationship: a multi-group analysis of innovation by Ugandan rural and urban entrepreneurs. Appl Psychol. 2016;65(1):99-131. doi:10.1111/apps.12033

118. Yang F, Zhao Y. The effect of job autonomy on psychological well-being: the mediating role of personal initiative. Open J Soc Sci. 2018;6 (11):234-248. doi:10.4236/jss.2018.611017

119. Kagan I, Hendel T, Savitsky B. Personal initiative and work environment as predictors of job satisfaction among nurses: cross-sectional study. BMC Nurs. 2021;20(1):1-10. doi:10.1186/s12912-021-00615-1

120. Thomas JP, Whitman DS, Viswesvaran C. Employee proactivity in organizations: a comparative meta-analysis of emergent proactive constructs. J Occup Organ Psychol. 2010;83(2):275-300. doi:10.1348/096317910X502359

121. Ng TW, Eby LT, Sorensen KL, Feldman DC. Predictors of objective and subjective career success: a meta-analysis. Pers Psychol. 2005;58 (2):367-408. doi:10.1111/j.1744-6570.2005.00515.x

122. Weigt-Rohrbeck J, Linneberg MS. Democratizing innovation processes: personal initiative in bottom-up eco-innovation. Eur J Innov Manag. 2019;22(5):821-844. doi:10.1108/EJIM-12-2018-0278

123. Zacher H, Schmitt A, Jimmieson NL, Rudolph CW. Dynamic effects of personal initiative on engagement and exhaustion: the role of mood, autonomy, and support. J Organ Behav. 2019;40(1):38-58. doi:10.1002/job.2277

124. Zappalà S, Toscano F, Polevaya MV, Kamneva EV. Personal initiative, passive-avoidant leadership and support for innovation as antecedents of nurses' idea generation and idea implementation. J Nurs Scholarsh. 2021;53(1):96-105. doi:10.1111/jnu.12615

125. Nsereko I, Balunywa WJ, Ntamu DN, Munene J, Babirye H. Personal initiative, entrepreneurial self-efficacy and social entrepreneurial venture creation. Small Enterprise Res. 2021;28(3):329-349. doi:10.1080/13215906.2021.1946131

126. Mensmann M, Frese M. Who stays proactive after entrepreneurship training? $\mathrm{N}$ eed for cognition, personal initiative maintenance, and wellbeing. J Organ Behav. 2019;40(1):20-37. doi:10.1002/job.2333

127. Lisbona A, Palaci F, Salanova M, Frese M. The effects of work engagement and self-efficacy on personal initiative and performance. Psicothema. 2018;30(1):89-96. doi:10.7334/psicothema2016.245

128. Ghasemzadeh Alishahi A. Mediating role of perceived control in the impact of personal qualities on job stress among hospital staff. Int $J$ Hosp Res. 2014;3(1):37-42.

129. Mykolenko O, Ippolitova I, Doroshenko H, Strapchuk S. The impact of entrepreneurship education and cultural context on entrepreneurial intentions of Ukrainian students: the mediating role of attitudes and perceived control. High Educ Ski Work-Based Learn. 2021. doi:10.1108/ HESWBL-08-2020-0190 
130. Morgeson FP, Delaney-Klinger K, Hemingway MA. The importance of job autonomy, cognitive ability, and job-related skill for predicting role breadth and job performance. J Appl Psychol. 2005;90(2):399-406. doi:10.1037/0021-9010.90.2.399

131. Khan HS, Ma Z, Chughtai MS, Li M. Investigation of cascading effects of perceiving a calling on occupational burnout: a mediated moderation model. Curr Psychol. 2021:1-11. doi:10.1007/s12144-021-02431-x

132. Hashim M, Baig SA, Amjad F, Nazam M, Akram MU. Impact of supply chain management practices on organizational performance and moderating role of innovation culture: a case of Pakistan textile industry. Paper presented at: International Conference on Management Science and Engineering Management; 2019.

133. Ali A, Khan M, Ishaq A, et al. Pakistan textiles can bounce back vigorously. Int Rev Manag Mark. 2020;10(2):30-40. doi:10.32479/irmm.9377

134. Memon JA, Aziz A, Qayyum M. The rise and fall of Pakistan's textile industry: an analytical view. Eur J Bus Manag. 2020;12(12):136-142.

135. Safeer AA, He Y, Abrar M, Ullah A. Diagnostics of the challenges and potential solutions to improve export competitiveness in international markets: the case of Pakistani readymade garments industry. $J$ Competitive. 2019;11(3):128-143. doi:10.7441/joc.2019.03.08

136. Anjum A, Sabir HM, Hussain MS, Hussain MS. Effort-enhancing HR practices and innovative work behavior: role of employee empowerment. Int J Acad Res Bus Soc Sci. 2016;6(10):2222-6990. doi:10.6007/IJARBSS/v6-i10/2362

137. Brasil M, Abreu M, Silva J, Leocádio AL. Relationship between eco-innovations and the impact on business performance: an empirical survey research on the Brazilian textile industry. Revista de Administração. 2016;51:276-287. doi:10.1016/j.rausp.2016.06.003

138. Zia-Ur-Rehman M, Baig SA, Abrar M, et al. The impact of intellectual capital, organizational capabilities and innovation on firm performance of textile sector: a moderating effect of GSP plus. Ind Textila. 2019;70(6):572-578. doi:10.35530/IT.070.06.1632

139. Shafi M, Yang Y, Khan Z, Vertical YA. Co-operation in creative micro-enterprises: a case study of textile crafts of Matiari district, Pakistan. Sustainability. 2019;11(3):920-936. doi:10.3390/su11030920

140. Podsakoff PM, MacKenzie SB, Podsakoff NP. Sources of method bias in social science research and recommendations on how to control it. Ann Rev Psychol. 2012;63:539-569. doi:10.1146/annurev-psych-120710-100452

141. Harman D. A single factor test of common method variance. J Psychol. 1967;35(1967):359-378.

142. Robitschek C. Personal growth initiative: the construct and its measure. Meas Eval Couns Dev. 1998;30(4):183-198. doi:10.1080/ 07481756.1998 .12068941

143. Zheng J, Wu G, Xie H. Impacts of leadership on project-based organizational innovation performance: the mediator of knowledge sharing and moderator of social capital. Sustainability. 2017;9(10):1-22. doi:10.3390/su9101893

144. Hair JF, Hult GTM, Ringle C, Sarstedt M. A Primer on Partial Least Squares Structural Equation Modeling (PLS-SEM). Sage publications; 2017.

145. Hair JF, Black WC, Babin Barry J, Anderson R. Multivariate Data Analysis. 7th ed. Upper Saddle River, NJ: Prentice Hall; 2010.

146. Ramayah T, Lee JWC, In JBC. Network collaboration and performance in the tourism sector. Serv Bus. 2011;5(4):411-428. doi:10.1007/ s11628-011-0120-z

147. James G, Witten D, Hastie T, Tibshirani R. Statistical learning. In: An Introduction to Statistical Learning. New York: Springer; $2013: 15-57$.

148. Hair JF, Ringle CM, Sarstedt M. PLS-SEM: indeed a silver bullet. J Market Theor Pract. 2011;19(2):139-152. doi:10.2753/MTP10696679190202

149. Bagozzi RP, Yi Y. On the evaluation of structural equation models. J Acad Mark Sci. 1988;16(1):74-94. doi:10.1007/BF02723327

150. Perry Hinton D, Hinton PR, McMurray I, Brownlow C. SPSS Explained. Routledge; 2004.

151. Fornell C, Larcker DF. Evaluating structural equation models with unobservable variables and measurement error. J Mark Res. 1981;18 (1):39-50. doi:10.1177/002224378101800104

152. Grégoire Y, Fisher RJ. The effects of relationship quality on customer retaliation. Mark Lett. 2006;17(1):31-46. doi:10.1007/s11002-006-3796-4

153. Henseler J, Ringle CM, Sarstedt M. Using partial least squares path modeling in advertising research: basic concepts and recent issues. In: Okzaki S, editor. Handbook of Partial Least Squares: Concepts, Methods and Applications in Marketing and Related Fields. Berlin: Springer; 2012:256-272.

154. Cohen J. Statistical Power Analysis for the Behavioural Sciences. Hillsdale, New Jersey: Laurence Erlbaum Associates, Publishers; 1988.

155. Burns RP, Burns R. Business Research Methods and Statistics Using SPSS. London: Sage Publications; 2008.

156. Joanna Samul W. Spiritual dimensions in leadership: a comparative analysis of Polish and Bhutanese managers. Psychol Res Behav Manag. 2021;14:847-856. doi:10.2147/PRBM.S311456

157. Huang N, Qiu S, Yang S, Deng R. Ethical leadership and organizational citizenship behavior: mediation of trust and psychological well-being. Psychol Res Behav Manag. 2021;14:655-664. doi:10.2147/PRBM.S311856

158. Liang F, Cao L. Linking employee resilience with organizational resilience: the roles of coping mechanism and managerial resilience. Psychol Res Behav Manag. 2021;14:1063-1075. doi:10.2147/PRBM.S318632

159. Chin WW. How to write up and report PLS analyses. In: Handbook of Partial Least Squares. Springer; 2010:655-690.

160. Abbas W, Wu W. Organizational justice, leader humility, and service employees' innovative behavior in a collectivistic culture: the case of Pakistan. Revista Brasileira de Gestão de Negócios. 2021;23(1):153-179.

161. Owens BP, Hekman DR. How does leader humility influence team performance? Exploring the mechanisms of contagion and collective promotion focus. Acad Manag Ann. 2016;59(3):1088-1111. doi:10.5465/amj.2013.0660

162. Putra TRI, Harmen H, Suryani AI, Fadilah I. The effect of work engagement and self-efficacy on individual performance mediated by personal initiative: study in students. Paper presented at: Proceedings Aceh Global Conference-Business, Economics, and Sustainable Development Trends; Banda Aceh, Indonesia; 2020.

163. Rigby CS, Ryan RM. Self-determination theory in human resource development: new directions and practical considerations. Adv Dev Human Res. 2018;20(2):133-147. doi:10.1177/1523422318756954 


\section{Publish your work in this journal}

Psychology Research and Behavior Management is an international, peer-reviewed, open access journal focusing on the science of psychology and its application in behavior management to develop improved outcomes in the clinical, educational, sports and business arenas. Specific topics covered in the journal include: Neuroscience, memory and decision making; Behavior modification and management; Clinical applications; Business and sports performance management; Social and developmental studies; Animal studies. The manuscript management system is completely online and includes a very quick and fair peer-review system, which is all easy to use. Visit http://www.dovepress.com/testimonials.php to read real quotes from published authors.

Submit your manuscript here: https://www.dovepress.com/psychology-research-and-behavior-management-journal 